\title{
HORIZONTAL AND VERTICAL RESTRAINTS OF TRADE: THE LEGALITY OF MOTION PICTURE SPLITS UNDER THE ANTITRUST LAWS
}

\section{JAMES S. GORDON $\ddagger$}

Harry SLEY, Philadelphia garage owner and sometime theatre operator, recently went to court to overhaul the mechanics of motion picture film distribution. As owner of the now defunct Viking Theatre in Philadelphia, Sley sued his major competitors, the Stanley Warner Corporation and William Goldman Theatres, Inc., for damages resulting from their alleged conspiracy with the major motion picture distributors. In the trial court, the gravamen of the complaint was a conspiracy among Goldman, Stanley Warner, and six major distributors allegedly resulting in discriminatory treatment against Viking. Invoking the Sherman Act, Sley attempted to prove that his bids for film product were rejected despite their superiority to his competitors' bids, that he was discriminatorily denied rental adjustments and adjustments on the playing time for films he did receive, that he was required to play pictures for an excessively long time while Stanley Warner and Goldman had more rapid turnover, and finally, that he was required to pay more than his competitors for films he received. Suffering a directed verdict on these grounds, he changed his argument in the Court of Appeals for the Third Circuit. To his list of complaints, Sley added the allegation that his competitors' agreement to split or allocate film product between them, without bidding competitively for it, was a per se violation of the antitrust laws. Both the old and the new arguments were rejected by the Court of Appeals. ${ }^{1}$ Before the Supreme Court, Sley ignored the case he tried below, and, concentrating exclusively on the Goldman-Stanley Warner agreement to split product, he argued that such a split was per se illegal because it did not include all exhibitors. The final round in the litigation ended in a draw. Faced with the necessity of deciding the legality of "splits," the Court itself split four-four, affirming per curiam the decision for defendants below. ${ }^{2}$ In the absence of an authoritative

$\dagger$ Member, Illinois Bar; Member, Board of Editors, Volume 74.

1. Viking Theater Corp. v. Paramount Film Distrib. Corp., 320 F.2d 285 (3d Cir. 1963), aff'd per curiam, 378 U.S. 123.

2. Ibid. 
Supreme Court opinion, the affirmance of the Court of Appeals decision left the opinion below as another landmark in the continuing antitrust litigation over the legality of splits.

In Viking and its kindred cases, the theatre operators of a given local exhibition market have agreed to divide the available film product among themselves, each obtaining an aliquot part for which the others would not compete.

In practice this amounts to taking a group of pictures on the release schedules of one or more distributors and dividing the pictures, assuming two theatre circuits, into two equal lists. The one who did not arrange the lists has the right to the first choice of lists. The next group of films will be split into two lists by the other party, and again the one who did not do the arranging will have the first choice. ${ }^{3}$

This method of allocating films simply throws all films to be released during a particular period of time into one hotchpot and provides for its division by agreement among exhibitors without regard to the distributor and without competitive bidding for the allocated product. So described, splits stand out clearly as agreements not to compete, alarmingly similar in design and impact to other such agreements well known to antitrust lawyers since the turn of the century. Unlike other forms of market division which have customarily been held per se illegal under the Sherman Act, splits not only have avoided this fate, but have obtained the endorsement of the Department of Justice. ${ }^{4}$

An additional peculiarity is that the parties most directly aggrieved by the elimination of competition among film exhibitors-the film distributors whose revenues would rise were competitive bidding the rule-have in most cases acquiesced. Many explanations have been offered for this passivity, some conflicting, some confusing, and some

3. Comment, An Experiment in Preventive Antitrust: Judicial Regtulation of thc Motion Picture Exhibition Market Under the Paramount Decrees, 74 YALE L.J. 1040, 1109 (1965) [hereinafter cited as COMMENT]; for a general discussion of splits sec CoMmENT at 1062, 1072-74 and 1108-10.

4. See Testimony of Assistant Attorney General Barnes, Hearings Before Subcommiltec of the Senate Select Committee on Small Business, 83d Cong., 1st Sess., at 651.52 (1953). For an example of the Justice Department's reaction to a split involving all local cxhibitors, see Letter from Assistant Attorney General Loevinger to Edward Bennett Williams, Esq., dated June 25, 1962, Appendix to Brief for Petitioner, pp. 3a-4a, Viking Theater Corp. v. Paramount Film Distrib. Corp., supra note 1. On this occasion, however, the Justice Department refused to comment on the legality of splits in gencral. See also Bork, The Rule of Reason and the Per Se Concept: Price Fixing and Market Division, 74 YalE: L.J. 775, 826 (1965) [hereinafter cited as BoRK]. 
which seem to have no economic basis. 5 The most plausible explanation suggests that any course of action other than distributor acquiescence is excessively costly. Faced with a split, a distributor who refuses to acquiesce can either refuse to deal with the conspiring exhibitors or sue them on an antitrust claim for the damages he sustains. Both alternatives would require the distributor to jeopardize the ongoing relationship between a supplier and his outlet in a market where the latter provides the total source of revenue. Bringing suit against the exhibitors is apparently fraught with another kind of risk. Distributor and exhibitor counsel suggest that this course of action would result in an immense volume of litigation the ultimate cost of which might be greater to nonacquiescing distributors than the costs of tacit acquiescence. Although these explanations may not seem persuasive, apparently they have encouraged distributor acquiescence and discouraged a concerted pattern of litigation by distributors to test the legality of splits. Two facts are certain, however. Splits are the prevailing mode of market allocation for film product. ${ }^{\circ}$ And thus far the isolated judicial reaction to splits has been puzzling.

Review of the presently reported opinions dealing with splits indicates that each of the several theories of legality is created out of

5. The following explanations are most frequently offered for distributor aquiescence: (a) splits give the distributor certainty of play dates and market coverage for all his product; (b) splits allow booking far in advance of the date booking would take place in a competitive market, since, without competitive bidding, exhibitors will agree to license films "blind," that is, without seeing them at a special screening; (c) splits ensble distributors to give adjustments on film rentals when a film does poorly, adjustments which would be impossible under competitive bidding due to the fear of exhibitor suits based on alleged discrimination. See text accompanying notes 78-83 infra; (d) since splits allow adjustments of rental according to how well a film does, a split enables a sharing of risk between exhibitors and distributors which competitive bidding would prevent; (c) distributors willingly forego higher profits because they do not want "blood moncy"; (f) distributors fear litigation from dissatisfed exhibitors who lose out in competitive bidding. See text accompanying notes $78-83$ infra; (g) distributors try to preserve outlets to avoid monopsony in the exhibition market. See text accompanying notes 84-87 infra; (h) distributors fear to sue conspiring exhibitors for the reasons discussed in the tcxt, although it is well known in the industry that they send out letters to many local markets announcing their refusal to consent and their intention to hold the splituing exhibitors liable for damages. Interview with various exhibitor and distributor counsel, New York City, May 14,1965 .

6. Among the exhibition situations discussed in Comarenr, splitting of product was found to be the modus vivendi in San Jose, Cal., Suburban Philadelphia (Cheltenham), Pa., New Haven, Conn., Fayetteville, N.C., Poughkeepsic, N.Y., and Seattle, Wash., to mention only a few of many instances. For the prevalence of splitting and the relative scarcity of competitive bidding, see Cassady, Impact of the Paramount Decision on Motion Picture Distribution and Price Making, 31 So. CAL. L. REv. 150, 161-165 (1958). 
whole cloth. The first of these theories was formulated by Judge Palmieri in United States $v$. Loew's, Inc., ${ }^{7}$ where the National Theatres Circuit (National General) was petitioning under the Paramount decrees to acquire a new facility in San Jose, California. The petitioner's competitors appeared as amici curiae and protested the acquisition of the grounds that it would unduly restrain competition, claiming, among other things, that National's participation in a split demonstrated its anticompetitive proclivities. Judge Palmieri, the judicial overseer of the industry under the Paramount decrees, rejected the claim:

Concededly, any arrangement whereby exhibitors agree with each other that they will not compete in the buying of the product cannot be countenanced; although it is equally clear that splits of product with the consent of both distributors and exhibitors are proper. ${ }^{8}$

In reaching this conclusion, Judge Palmieri relied on Justice Douglas' opinion in United States $v$. Paramount Pictures, Inc., ${ }^{0}$ where the Court refused to force competitive bidding on the industry; on Royster Drive-in Theatres v. American Broadcasting-Paramount Theatres, ${ }^{10}$ a private treble damage suit; and on an article in the Southern California Law Review describing motion picture distribution practices. ${ }^{11}$ None of the three is authority for the proposition that distributor acquiescence renders legal what may be an otherwise illegal agreement not to compete. Paramount merely held that there were lawful means other than competitive bidding to allocate motion pictures; it did not hold that non-competitive allocation was permissible. Similarly, the law review article cited merely described splits; it presented no arguments for their legality. Finally, the Royster Drive-in case made no ruling at all on the legality of splits. In fact, the Court said,

Whatever the legality of this system-and we are not called upon to deal with that issue here-it probably tends to keep more exhibitors in business than would be the case if competitive bidding were the universal rule. ${ }^{12}$

7. Trade Rec. REP. (1962 Trade Cas.) If 70347, at 76378 (S.D.N.Y. June 1, 1962).

8. Id. at 76374 .

9. 334 U.S. $131,162,165-66$ (1948).

10. 268 F.2d 246 (2d Cir. 1959).

11. Cassady, Impact of the Paramount Decision on Motion Picture Distribution and Price Making, supra, note 6.

12. 268 F.2d 246, 250 (2d Cir. 1959), (Emphasis added). The Royster case was particularly interesting in that plaintiff seems to have attacked the legality of competitive bldding. As might be expected, the Second Circuit upheld the legality of competition, ibid. 
Despite the absence of support, so impressive was Judge Palmieri's statement of the law that the Ninth Circuit accepted it without question. However, in this case, Samuel Goldwyn Productions, Inc. v. Fox West Coast Theatres Corp., ${ }^{13}$ a producer's $^{14}$ product was split by exhibitors without his consent. Therefore, the court upheld a $\$ 300,000$ verdict in favor of the producer.

A second theory of legality, although developed in disregard of Palmieri's rule, has a similarly vague origin and rests upon equally dubious foundations. This theory seems to have been specially formulated by the Third Circuit in response to Harry Sley's contention in Viking that a split which does not include all exhibitors in the relevant competitive area is per se unlawful under the Sherman Act. The court, careful to point out that the legality of splits in general was not in issue, went on to develop, on the facts presented in Viking, the following rule:

... [T] he failure to include all exhibitors in the split system will not render it illegal in the absence of evidence that it was so employed as to unreasonably restrict the competitive market, or had this result. [Giting Brown v. Western Massachusetts Theatres, Inc. and Schad v. Twentieth Century-Fox Film Corp.] ${ }^{15}$

At the outset, it should be noted that the Third Circuit's emphasis on the effect of the split on competition renders distributor acquiescence irrelevant; the presence or absence of acquiescence could hardly alter the competitive effect of a split in any given exhibition market. In fact, had acquiescence been considered significant, the decision might have gone the other way, because, as to at least two of the major distributors joined as defendants, the court found no evidence of acquiescence. ${ }^{16}$ Second, the Viking rule has no precedential support; the two cases upon which the Court apparently relied are far from controlling. Brown v. Western Massachusetts Theatres, Inc. ${ }^{17}$ involved a private treble damage action brought by an exhibitor in Greenfield, Massachusetts, against his competitors and the major film distributors.

13. 194 F. Supp. 507 (N.D. Cal. 1961), aff'd sub nom. Twenticth Century Fox Film Corp. v. Samuel Goldwyn Prods., Inc., 328 F.2d 190 (9th Cir.), cert. denied, 379 U.S. 880 (1964).

14. Producers and distributors are, in the case of the seven majors, vertically integrated, and in all other cases herein will be treated as if they were, since the producers' and distributors' interests are identical.

15. 320 F.2d at 293.

16. "There is no direct evidence that Columbla or UNrversar acquiesced in the split, but their pictures were, nevertheless, included on lists prepared by StaNLEx Warker and Goldman." Id. at 292.

17. 288 F.2d 302 (1st Cir. 1961). 
Plaintiff argued neither that splits were per se illegal nor that they were illegal, as Sley argued, only when all exhibitors were not mem. bers. The gravamen of Brown's complaint was "that the distributors jointly agreed with the exhibitors [plaintiff's competitors] to divide the bulk of their first run product ... thus depriving plaintiff of an op. portunity to obtain the supply of first run pictures needed for effective competition."18 All plaintiff could prove was the bare fact that his two competitors did not bid against each other for product; he did not prove the existence of an agreement to split such as was established in Viking. Relying therefore on the doctrine of parallel action, ${ }^{10}$ Brown was required to show that the rational explanation of the parallel behavior was a conspiracy to deprive him of product. However, the Court found that the most rational explanation of the parallel behavior was the desire to avoid ruinous competition:

Competitive bidding was suicidal for exhibitors. The Antitrust laws do not require a business to cut its own throat. Even plaintiff himself resisted three-way bidding, and in place of this, all three exhibitors (including plaintiff) ultimately agreed on a division of the first run movies of the several distributors. ${ }^{20}$

It is therefore obvious that the decision in Brown has no bearing whatever on cases involving (l) a proven agreement to split product with distributor participation; (2) an attack on the legality of a proven agrecment; or (3) an attack, as in Viking, on the agreement because it does not include all exhibitors. Consequently, citation of Brown by the Third Circuit in support of its rule is inexplicable.

More inexplicable, however, is the citation of Schad $v$. Twentieth Century Fox Film Corp., ${ }^{21}$ a case decided in 1943 before the Paramount litigation. The law on which the Schad court relied in regard to the allocation of product between theatres has been superseded completely by the Paramount decrees. In Schad, the court sustained a dismissal of the complaint. Today the plaintiff would be entitled to summary judgment. Schad is not merely bad law; after Paramount it

18. Id. at 304 .

19. This doctrine holds that, in the absence of any rational business justification for closely similar behavior by businessmen, a conspiracy will be inferred, especially where each actor was fully aware of the other's behavior. See Theatre Enterprises Inc. v. Parrimount Film Distrib. Corp., 346 U.S. 537 (1954); Interstate Circuit, Inc. v. United States, 306 U.S. 208 (1939); Delaware Valley Marine Supply Co. v. American Tobacco Co., 297 F.2d 199 (3d Cir. 1961).

20. $288 \mathrm{~F} .2 \mathrm{~d}$ at 305 . Ultimate agreement came after the period in suit.

21. 136 F.2d 991 (3d Cir. 1943). 
is a paradigm case of restraint of trade in motion picture exhibition. ${ }^{22}$ Thus the Third Circuit's rule purports to be derived from precedent which in fact is non-existent. Like Judge Palmieri's rule of distributor acquiescence, the rule in Viking is entitled to no more weight than any ipse dixit can obtain from the reasons given in its support. Unfortunately, no reasons were given, and it is puzzling that an agreement not to compete which destroys all competition in a relevant market is legal unless it can be proved that such agreement unreasonably restrains competition in that market. After all, such agreements not to compete are not res nova, and it is well settled that regardless of their reasonableness, they are conclusively presumed illegal.23

Judge Palmieri's rule and the Third Circuit's rule, despite their dubious origins, are now the law of the land. Seldom has the law on

22. Schad provides a beautiful illustration of a bygone era of distribution and cxhibition practices. Defendant Warner Bros. Circuit had been leasing plaintiff Schad's Astor Theatre in Reading, Pennsylvania, and by contractual arrangement with Twentieth Century Fox, Warner was playing half of Fox's product on first run. Defendant Wilmer \& Vincent Theatre Co. was playing the other half at its Embassy. W'hen Warner's lease on plaintiff's Astor expired, it leased the State, a subsequent-run house owned by Wilmer \&. Vincent, and moved it up to first run. The "undisputed facts" beyond the ensuing arrangement are stated by the court:

Wilmer \& Vincent, which had been seeking the right to exhibit the entirc Fox product, now conditioned its agreement to lease the State to Warner upon Wamer's relinquishing its claim to one-half of the Fox product. On November 7, 1940, Warner surrendered its Fox contract and on November 29, 1940, Fox exceuted a contract giving Wilmer \& Vincent all of the Fox product for a three jear period, the Fox pictures to be exhibited at the Embassy and the Ritz [a Wilmer \& Vincent theatre, which the court described as "B Grade"]. From November, 1940 to Mray, 1941 Warner operated the Astor without Fox pictures. After Warner moved to the State it exhibited Vitagraph pictures alone. After May, 1941, the plaintifs, who were without sufficient pictures to run at the Astor, entered into a five year pooling agreement with Emmanuel [a competitor] ... whereby the best pictures available to the pool were to be played at the Astor. . . . The pooling agreement cost the plaintiffs $\$ 50,000$ a year. During the 1940-41 season Wilmer and Vincent had under contract 70 pictures, each to be exhibited for a week. Some of the Fox films were exhibited at the State or Ritz, which theatres paid lower rentals for them than the Embassy or Astor.

136 F.2d at 995.

Under the existing case law, the above statement of facts is wholly sufficient to prove that the particular split in court in Schad was, to use the Third Circuit's language in Diking, "so employed as to unreasonably restrict the competitive market, or had this result." 320 F.2d at 293. Thus the Schad case is totally inappropriate for the purpose for which it was cited.

23. See, e.g., United States v. Socony-Vacuum Oil Co., 310 U.S. 150 (1940) (price fixing); United States v. Trans Missouri Freight Assn., 166 U.S. 290 (1897) (price fixing); United States v. Addyston Pipe \& Steel Co., 85 Fed. 271 (6th Cir. 1898), aff'd, 175 U.S. 211 (1899) (market division). See generally, Bork. 
so important a subject been so obscure. It is clear that in a suit brought by a distributor against exhibitors, his acquiescence vel non is determinative under the Palmieri rule. When the distributor does not acquiesce, it is unclear whether Palmieri's rule protects him from a suit by an exhibitor who refuses to participate in an existing split; in Viking two distributors who apparently did not acquiesce were not dismissed as defendants. ${ }^{24}$ When an exhibitor sues, alleging that a split is unlawful solely on the grounds that it does not include all exhibitors, it is reasonably certain that under the Viking rule he will have to prove only that the split was so "employed as to unreasonably restrict the competitive market, or had this result."25 He apparently need not concern himself with distributor consent. And in some cases it may be unclear whether either the Viking rule or the Palmieri rule applies, or whether a combination of both is required. ${ }^{20}$

Although the present law on splits is obscure in origin as well as in application, what is far more remarkable is that the opinions seem to have been written in a vacuum, completely independent of the traditional antitrust rules governing market division and price fixing, two restraints which seem too closely analogous to be ignored.

Market divisions between competitors have always been condemned as inconsistent with the Sherman Act because they have no other purpose than to stifle competition. In one of the first cases arising under the Sherman Act, United States v. Addyston Pipe \& Steel Co., ${ }^{27}$ the Court found illegal an agreement between competing manufacturers of pipe to divide the market by assigning each party to the agreement an exclusive territory in which no other member could compete. Despite the defendants' argument that the agreement prevented ruinous

\footnotetext{
24. See note 16, supra.

25. $320 \mathrm{~F} .2 \mathrm{~d}$ at 293.

26. This confusion is illustrated by the charge given a Connecticut jury, upon defendants' request, which merged Palmieri's rule on distributor acquicscence and the Viking rule (somewhat doctored) on unreasonable restraints. Judge Claric charged:

It has been testified that during certain periods the exhibitors in New Britain and in Hartford agreed to a "split of product," so-called, to avoid competitive bidding. ... In the absence of any showing that the split of product was a part of a plan to monopolize or to conspire in restraint of trade, there is nothing illegal about a divi. sion ... of product between motion pictures exhibitors, with the concurrence or acquiescence of the distributors concerned.

Berlin Drive-In Theatre v. Stanley Warner Management Corp., Civil case No. 8501 (D.C. Conn. 1965) (unreported). Plaintiff exhibitor sued the distributors and his compctitors who participated in a split which he had refused to join for depriving him unreasonably of the film product he wanted on the run he thought his theatre deserved. Defendants won the jury verdict and were awarded their costs.
}

27. 85 Fed. 271 (6th Cir. 1898), aff'd, 175 U.S. 211 (1899). 
competition, Judge Taft stated that "[n]o matter what the excuse for the combination by defendants in restraint of trade, the illegality of the means stamps it as a conspiracy, and so brings it within that term of the federal statute." 28 This rule of per se illegality has been reaffirmed many times and includes closely analogous restraints such as price fixing. ${ }^{29}$ In all of these cases, defendants have argued that unchecked competition in a free market would be ruinous, and in every one the Court has unequivocably rejected the argument. As Justice Douglas wrote in Socony-Vacuum, ${ }^{30}$

... [T]his Court has consistently and without deviation adhered to the principle that price fixing agreements [and division of markets] are unlawful per se under the Sherman Act and that no showing of so-called competitive abuses or evils which those agreements were designed to eliminate or alleviate may be interposed as a defense. ${ }^{31}$

This persistent animus against agreements not to compete has its origin in a long standing hostility to private interference with the pricing mechanism as a means of allocating society's economic resources. In the language of the Court,

Any combination which tampers with price structures is engaged in an unlawful activity. Even though the members of the pricefixing group were in no position to control the market, to the extent that they raised, lowered, or stabilized prices they would be directly interfering with the free play of market forces. The Act places all such schemes beyond the pale and protects that vital part of our economy against any degree of interference. Congress has not left with us the determination of whether or not particular price-fixing schemes are wise or unwise, healthy

28. 85 Fed. at 294.

29. See supra note 23. But cf., Chicago Bd. of Trade v. United States, 246 U.S. 231 (1918), where the setting of call prices on a grain exchange was upheld against a Sherman Act attack; Appalachian Coals, Inc. v. United States, 288 U.S. 344 (1933), where a joint selling agency among producers of bituminous coal was held legal despite the fact that price fixing was at the heart of the agency's operation. To the extent that these ases hold that agreements in restraint of trade, created for that purpose and with that effect, an be justified under the rule of reason, they have been thoroughly discredited. United States v. Socony-Vacuum Oil Co., 310 U.S. 150 (1910); United States v. Trenton Potteries Co., 273 U.S. 392 (1927). See also BoRk. However, to the extent that the cases first cited in this footnote show a willingness to permit agreements in restraint of trade which are ancillary to business relationships which have been entered into to obtain a greater efficiency or to achieve other valid purposes, those cases might support the analysis of motion picture splits which is advanced in the text accompanying notes 56-80. See particularly the discussion of the one defense of certain splits the validity of which is reasonably certain, in the text accompanying notes 75-80.

30. United States v. Socony-Vacuum Oil Co., supra note 29.

31. Id. at 218. 
or destructive. It has not permitted the age-old cry of ruinous competition and competitive evils to be a defense to price-fixing conspiracies. ... Whatever may be its peculiar problems and characteristics, the Sherman Act, so far as price-fixing agreements are concerned, establishes one uniform rule applicable to all industries alike. ${ }^{32}$

And the mere fact that a price-fixing scheme is vertically imposed by a manufacturer on its dealers or consented to by him will not save it. In United States v. Parke, Davis of Co., ${ }^{33}$ a resale price maintenance program vertically imposed on Parke, Davis' drug retailers was held per se illegal. As the Court stated,

The manufacturer is thus the organizer of a price-maintenance combination . .. in violation of the Sherman Act. Under that Act "competition not combination, should be the law of trade," ... and "a combination formed for the purpose and with the effect of raising, depressing, fixing, pegging, or stabilizing the price of a commodity ... is illegal per se."34

This hostility to interference with the price system derives from the belief that unimpeded price movements best allocate resources according to consumer desires. For example, it is a truism that when demand exceeds supply price will generally rise, thus encouraging resources to move into this now more profitable area, thereby incrensing supply. ${ }^{35}$ Although this is an oversimplification of a very complex economic theory, it still remains true by and large, that with free price movements, consumer wants determine the allocation of society's resources. ${ }^{36}$ When, therefore, artificial interferences with price are present, a misallocation results. Thus if prices are kept artificially high in a given area and barriers to new entry are low, overinvestment will occur. Conversely, if prices are kept artificially low, too few resources will be attracted to this sector of the economy and some consumer wants will go unsatisfied. In a freely competitive economy, all buyers or sellers are price takers. No one individual has the power to interfere with the market price determined by the impersonal interaction of supply and demand. When competition is eliminated, however, through agreements not to compete among vendors or purchasers,

32. Id. at 221-22.

33. 362 U.S. 29 (1960).

34. Id. at 47 (Emphasis added).

35. Leftwich, The Price System and Resource Allocation 14-15, 27-84 (rev. cl. 1965). See generally, SAMUELSON, Economics $367-78$ (3d ed. 1955).

36. LEFTwICH, supra note 35 , at $16,27-34$. For an intensive and technical analysis of the operation of supply and demand and the role of consumer choice in the process, sec Scrtovsky, WeLfare aND CoMpetTtion, ch. 1 and generally (rev. ed. 1955). 
power over price and output results. Although many purposes for the antitrust laws have been suggested, all courts and commentators have always agreed that the major impetus behind these laws was the fear of the power over price and output which had been obtained by the large trusts. ${ }^{37}$ For this reason, preservation of competition has always been considered the foundation of the antitrust laws. ${ }^{38}$ It is against this background that the market division and price-fixing cases discussed above must be read. Market division among competitors eliminates all competition between them in a given area, and price fixing eliminates competition in the most important aspect of a sale or purchase.

Both the law and economics set forth above seem as applicable to splits as to the traditional types of agreements not to compete. An agreement whereby exhibitors decide not to bid against one another for film product, such product being in shorter supply today than ever before, ${ }^{39}$ seems to have no other purpose than to lower prices. In fact, in most instances when splits have appeared in court there is undisputed evidence that distributors received lower than competitive prices. In the Royster Drive-in case, for example, the Court made the following statement:

The so-called "split" system, whereby exhibitors divide the list of available pictures and then approach the distributors separately on that basis, enables them to purchase films at lower prices. ${ }^{40}$

And Simon Fabian, the President of the Stanley Warner Corporation, testified in Viking that the sole purpose of the Philadelphia split was to eliminate all competition between his and the Goldman theatres,"11 thereby increasing the number of films on which his theatres had no competition whatsoever. These films might therefore be obtained at lower prices by negotiating with the distributor who had no alterna-

37. See Thorelit, The Federal ANTIIRUst Policy 225-32 (1954).

38. See, e.g., United States v. Trenton Potteries Co., 273 U.S. 392, 397 (1927), where the Court stated:

Our view of what is a reasonable restraint of commerce is controlled by the recognized purpose of the Sherman Law itself. Whether this type of restraint [price fixing] is reasonable or not must be judged in part at least in the light of its effect on competition, for ... it cannot be doubted that the Sherman Law and the judicial decisions interpreting it are based upon the assumption that the public interest is best protected from the evils of monopoly and price control by the maintenance of competition.

39. See Comment at $1101, n$. 214.

40. 268 F.2d at 250.

41. Record, p. 79-82, cited in Brief for Petitioner, p. 7. 
tive Philadelphia outlet. ${ }^{42}$ In the same suit, William Goldman, the other party to the agreement, testified that competitive bidding was "disastrous" to his economic success ${ }^{43}$ because it drove up the price for films. ${ }^{44}$ These views were confirmed on behalf of the distributors by William Mansell, the Warner Brothers branch manager, who explained under cross examination in Viking that if there had been no split, and Goldman had been bidding against Stanley Warner for Warner Brothers' pictures, such bidding would have increased Warner Brothers' revenues. ${ }^{45}$

All available evidence indicates that similar testimony could be obtained from exhibition markets where splits are prevalent, from coast to coast. ${ }^{48}$ It is therefore beyond cavil that splitting interferes with the pricing mechanism by substituting private agreements not to compete for competitive price making. The net effect is a misallocation of some of the nation's economic resources and a distortion of the normal investment pattern. By collusively lowering their costs, exhibitors arrogate to themselves profits which would otherwise be earned by the producers. Thus exhibition becomes more profitable than it would be under competitive conditions, and production less profitable. As a result, exhibition commands too many resources, and production, too few. Accordingly it would be expected that without splitting there would be fewer theatres in existence. The accuracy of this prediction is illustrated by the exhibitors' most popular defense of their split system: "ruinous competition." The amici curiae brief for the nation's two largest exhibitor trade associations in the Viking case asserted that the Court should sustain the validity of splits because: "The primary benefit of splitting to exhibitors is survival. Films reach exhibitors who could not afford them under competitive bidding." 47 Moreover, it is an equally reasonable expectation that without splitting and with the concomitantly higher returns to producers a larger number of films would be produced. To the extent that the antitrust laws are meant to remedy misallocations of economic resources and the frustration of consumer wants, the motion picture exhibitors' agreement not to compete would seem the paradigm case

42. Record, p. 81-82, cited in Brief for Petitioner, p. 7.

43. Record, p. 1752, cited in Brief for Petitioner, p. 6.

44. Record, p. 1634-36, cited in Brief for Petitioner, p. 7.

45. Record, p. 2010, cited in Brief for Petitioner, p. 10.

46. The elimination of competition and the concomitant lowering of costs of film rentals to exhibitors was the intent and effect of splits in the situations cited in note 6 supra.

47. Brief for Theatre Owners of America, Inc. and Allied States Assoc. of Motion Picture Exhibitors, as amici curiae, p. 9. 
for the invocation of the per se rule against market division and price fixing.

In the context of the law which has emerged from over a half century of antitrust litigation, the two rules now governing splits seem particularly erroneous. Judge Palmieri's rule, which depends on the presence or absence of distributor consent in judging the legality of splits, has nothing whatever to do with competition. And the Viking rule, although asking whether or not a split has unreasonably restrained competition, presupposes that such an agreement not to compete, by itself and without more, is insufficient to establish a Sherman Act violation.

The doctrine that the consent of the party directly affected by an unlawful agreement not to compete renders that agreement legal is unique, to say the least, in antitrust law. Considering the concern of the antitrust laws to prevent misallocation of resources, ${ }^{18}$ it is obvious that acquiescence to a misallocation is totally immaterial. Moreover, in emphasizing distributor acquiescence, Palmieri's rule seems to have been created in total disregard of the law of resale price maintenance as crystallized in United States v. Parke, Davis \& Co..$^{40}$ If manufacturer imposition will not save an otherwise illegal combination tampering with price structure, certainly a less affirmative showing of consent in the form of mere acquiescence should not have this effect.

The Viking rule is similarly erroneous. It will be remembered that this rule holds splits failing to include all exhibitors legal in the absence of evidence that the split was employed to restrict competition unreasonably or had this effect. ${ }^{50} \mathrm{But}$ in fashioning this rule the Third Circuit, perhaps mindful of the per se illegality of any private agreement tampering with the price structure, relied on its finding that

There is no evidence in this record from which it may be inferred that any artificiality of price structure existed; in fact plaintiff made no attempt to offer such evidence. ${ }^{.1}$

Because this finding flies in the face of much of defendants' testimony, some of which has been described above, ${ }^{62}$ and ignores the general industry understanding of the purpose and effect of splits, ${ }^{63}$ it should

48. See notes $32,37,38$ supra.

49. 362 U.S. 29 (1960); see text at note 34 supra. See also United States v. Schrader's Son, Inc., 252 U.S. 85 (1920); Dr. Miles Medical Co. v. John D. Park \& Sons Co., 220 U.S. 373 (1911). Cf. United States v. Colgate \& Co., 250 U.S. 300 (1919).

50. See text accompanying note 15 supro.

51. 320 F.2d at 293 .

52. See text accompanying notes $41-45$ supra.

53. See text accompanying note 47 supra, for quotation from Brief for amici curiac, 
have been reversed by the Supreme Court as clearly erroneous. Stripped of the support provided by this erroneous finding, the court's rule is nonsense. If an agreement is conclusively presumed to be per se illegal because it is "a combination formed for the purpose and with the effect of raising, depressing, fixing, pegging, or stabilizing the price ..."54 it is hardly necessary also to prove that the agreement was "so employed as to unreasonably restrict the competitive market."65

If the reading of the governing antitrust law presented here is correct, splits are per se unlawful. Like price fixes and market divisions, exhibitor agreements not to compete in the licensing of film product interfere with the price mechanism and thereby misallocate resources. It is too late to argue, as the price fixers and market dividers have argued since the turn of the century, that ruinous competition is a defense to such antitrust violations. And to admit that splits protect exhibitors who would be eliminated by competition is but to acknowledge their pernicious effect.

A more respectable defense under present law, however, might be suggested. The argument is that if the distributor divides his own product among exhibitors, that is, if the split is vertically imposed, the per se rule is inappropriate. In only one Supreme Court case,

the nation's two largest exhibitor trade associations, which indicates the industry's bclicf in the effectiveness of splits in lowering prices for films and thus creating a price structure which could hardly be termed anything but "artificial." The effect achicved by the Stanlcy Warner and William Goldman companies in Philadelphia, text accompanying notes 41.45 supra, has been duplicated in most of the splitting situations known to the author.

54. United States v. Socony-Vacuum Oil Co., 310 U.S. 150, 223 (1940) (Emphasis added).

55. 320 F.2d at 293 (Emphasis added). If the facts contained in the record are reasonably complete, the Third Circuit should not be seriously criticized for the result affirmcd in tho Viking case. Careful examination of the record indicates that the plaintiff suffered a total failure of proof on the issue of whether the split of product between its competitors worked any damages to the Viking Theatre. There is no causal relationship to bc found in the full eight volumes of the record between the Viking's business losses and anything but the inexperience of its management and the high risks of the industry. Nor is there any convincing evidence to support the allegation of conspiracy between the distributors and Viking's competitors. Under the test suggested by this article, text following note $\mathbf{5 6}$ infra, certain aspects of the Philadelphia split may appear illegal. Notwithstanding this prospect, however, before a plaintiff can establish a claim for damages, an unbroken chain of Sherman Act cases holds that he must show that his damages were caused in substantial part by the illegal agreement not other factors. Pollock, The "Injury" and "Causation" Elements of a Treble-Damage Antitrust Action, 57 Nw. U.L. Rev. 691 (1963); Notc, Standing to Sue for Treble Damages under Section 4 of the Claylon Act, 64 CoLum. L. REV. 570 (1964). Research points to the tentative conclusion that it is unlikcly that a theatre owner not participating in a split of product among his competitors can be damaged by it. Rather, he might profit: his competition is diminished and he is able to compete for all films he may desire to exhibit, not merely for some part of them as he would be were he a participant. 
White Motor Co. v. United States, 50 has a similar defense rescued an otherwise illegal market division. In White Motor the Court faced a market division which, like splits in the motion picture industry, totally destroyed all competition between the dealers of a major national truck manufacturer. ${ }^{57}$ Three Justices, in vigorous dissent, would have applied the per se rule:

the rule of reason is inapplicable to agreements made solely for the purpose of eliminating competition. . . . To admit, as does petitioner, that competition is eliminated under its contracts is, under our cases, to admit a violation of the Sherman Act. No justification, no matter how beneficial, can save it from that interdiction. ${ }^{58}$

The majority, however, was persuaded by the defendant's argument that the market division in this case was distinguishable from those in the cases supporting the dissenters' view, since here the market division appeared to be vertically imposed. Conceding the per se illegality of horizontal market division agreements, the majority was unsure whether vertical territorial limitations deserved such treatment. In a display of candor, the majority said, "We do not know enough of the economic and business stuff out of which these arrangements emerge to be certain [of their illegal purpose and effect]." issue, the Court reversed an order granting summary judgment for the United States and remanded for trial. Justice Brennan in a concurring opinion made it clear that if after trial it appeared that the arrangement was prompted primarily by the dealers rather than by White, he would then vote with the dissenters. ${ }^{60}$ For, in that event, the territorial division would be more analogous to the horizontal restraints traditionally prohibited by the per se rule. IVhite Motor, therefore, indicates that when a market allocation restraint among competing businessmen does not originate with them, but rather is forced upon them by their supplier, the Supreme Court will not apply the rule of per se illegality-instead, the Court will permit the introduction of evidence on economic justifications for such behavior.

Consequently, if splits can be saved from per se illegality by the rule of reason, it must be accomplished under the majority rationale in the White Motor case. It is important to emphasize that the exemp-

\footnotetext{
56. 372 U.S. 253 (1963).

57. $I d$. at $255,256$.

58. Id. at 281 .

59. Id. at 263 .

60. Id. at 267 .
} 
tion from per se illegality extended by that case is narrowly circumscribed. First, the majority opinion was written by Mr. Justice Douglas who also authored some of the Supreme Court's more rigorous expressions of the per se rule. ${ }^{61}$ Second, the exemption is limited to vertically imposed market divisions; vertically imposed price fixing having been declared per se illegal in the resale price maintenance cases. ${ }^{62}$ Third, even this limited dispensation may be temporary, for

61. See, e.g., United States v. Socony-Vacuum Oil Co., 810 U.S. 150 (1940).

62. See Dr. Miles Medical Co. v. John D. Park \& Sons Co., 220 U.S. 878 (1911). This rule has been modified somewhat by United States v. Colgate \& Co., 250 U.S. 800 (1919), as interpreted and limited in United States v. Parke, Davis \& Co., 362 U.S. 29, 44 (1960), where the Court held that a manufacturer has the right to announce its policy to refuse to deal with retailers who do not resell at fixed retail prices and may cnforce that policy by actually refusing to deal with them. If the manufacturer's actions, however, go beyond a mere refusal to deal, he has transcended the Colgate exception and his actions constitute a per se violation of the Sherman Act.

White Motor seems to be inconsistent with this per se rule against vortically imposed price fixing, since price fixing has the same economic results as market divisions and has previously been similarly treated by the courts. See BoRk at $778 \mathrm{n} .8$. Fortunately for motion picture exhibitors and distributors, their splitting device is more closely analogous to the market division in White Motor, than to the resale price maintenance in Dr. Miles.

White Motor and Dr. Miles can however be read as consistent with one another. In Dr. Miles, the supplier raised in defense of its resale price maintenance program the vertical argument that without fixed resale prices "confusion and damage" would result. The Court rejected this defense, stating:

But the advantage of established retail prices primarily concerns the dealcrs. . . .

It is through the inability of the favored dealers to realize these profits, on account of the described competition, that the complainant works out its alleged injury. 220 U.S. at 407.

It was only after finding that the vertical benefit to Dr. Miles was the same as the benefit to its dealers that the Court went on to equate these vertical restraints with the horizontal restraints traditionally condemned as per se illegal.

[T] he complainant can fare no better with its plan ... than could the dealers themselves if they formed a combination and endeavored to establish the same restrictions, and thus to achieve the same result, by agreement with each other. If the immediate advantage they would thus obtain would not be sufficient to sustain such a direct agreement, the asserted ulterior benefit to the complainant cannot be regarded as sufficient to its system.

Id. at 408 .

In White Motor, however, the Court was faced with an entirely different situation. White argued that despite the effect of its territorial market division on the elimination of horizontal competition among its dealers, the benefits derived from the scheme-cnergetic sales and service efforts by its dealers and the avoidance of dealers in some territories obtaining "free rides" on the sales promotion and service of dealers in other territoricsaccrued exclusively to White and not to its dealers. Justice Brennan in his concurrence points to the fact that White's arrangements "bind the dealers to a rather harsh bargain while leaving the manufacturer unfettered." 372 U.S. at 267. And the majority saw some horizontal competition if it appeared from the trial that the attendant benefits accrued directly to White and thereby enabled it to wage more cffective competitive warfarc.

White Motor and $D r$. Miles can be reconciled, therefore, on the ground that what appears to be a horizontal elimination of competition is per se unlawful unless the restraint is 
White Motor resulted in nothing more than a remand for trial and the taking of evidence on the competitive effects of the restraint. As Justice Douglas stated,

... [W] do not intimate any view on the merits. We only hold

that the legality of the territorial and customer limitations should

be determined only after a trial. ${ }^{03}$

Such a trial might have indicated that the justifications for the restraint were illusory or that the anti-competitive effects were too "pernicious."64 In light of these caveats, the White Motor case, to say the least, is an uncertain precedent. Nevertheless, since the case may indicate the existence of an exception to the per se rule, the possibility that splits might be defended under White Motor as vertically imposed market divisions should be considered.

To demonstrate distributor imposition satisfactory under White Motor, a severe burden of proof must be borne by the distributor. In addition to proving that he was organizer and architect of the split, a distributor would probably also have to prove that his sole intent was to obtain direct and substantial benefits for himself. strongest case for a distributor would be one in which the exhibitor

vertically imposed, benefits directly the party imposing the scheme, and increases his competitive potential. In Dr. Miles where no truly vertical benefit was found, the Court held the price fixing scheme per se illegal; in White Motor where a vertical benefit distinct from the benefit accruing to the dealers from the elimination of competition inter sese was argued, the Court refused to apply a per se rule and remanded instead for a trial.

This distinction is not without precedent in antitrust law. In fact in the first case declaring horizontal market divisions per se illegal, United States v. Addyston Pipe \&: Steel Co., 85 Fed. 271 (6th Cir. 1898), aff'd, 175 U.S. 211 (1899), Judge Taft laid the basis for this distinction by holding that some restraints on competition were not unlawful if they were ancillary-collateral and subordinate-to a legitimate main purpose and neceseary to effectuate it. White's restraints would therefore qualify as ancillary to a legitimate main purpose-waging more effective competition-while Dr. Miles' would not, since, as the Court found, the elimination of horizontal competition was the main purpose of the scheme and any vertical benefit derived was only ulterior, indirect and indistinguishable from the benefit the dealers would derive by eliminating competition inter sese.

63. 372 U.S. at 264.

64. Id. at 262. Unfortunately, from the view of developing law, the White Motor case was settled by consent decree after remand. United States v. White Motor Co., TrADE REc. REP. (1964 Trade Cas.) If 71195, at 79762 (N.D. Ohio. Sept. 8, 1964).

65. Thus far, the emphasis has been on the White Motor vertical imposition approach from the vantage point of the distributor who is joined as a defendant in a suit such as $\nabla$ iking or Berlin Drive-In; but this defense is, of course, equally available to the exhibitordefendant who has participated in a split. If the White Motor test is met, and the split is vertically imposed, the existence of a horizontal conspiracy among exhibitors is unlikely to be established, and the test itself rules out the existence of an exhibitor-distributor conspiracy in restraint of trade. 
members of a split were unwilling without coercion to accept such a restraint, a substantial case could probably still be made where the exhibitors also had something to gain. The important point, however, is that the benefit to the distributor must be the primary motive for the agreement to split.66 If this statement of the law is correct, it is apparent that mere distributor acquiescence, as required under the Palmieri rule, could not possibly be sufficient for this purpose. If White's dealers had divided territories and agreed not to compete, and then obtained White's acquiescence to their arrangement, the Supreme Court would unquestionably have held the arrangement per se illegal. ${ }^{.7}$

In most of the cases, however, the splitting arrangement appears to be a straight exhibitor cartel. ${ }^{88}$ Judge Clarie's charge to a Hartford, Connecticut jury in a suit by an exhibitor against his competitors and the distributors is representative:

You have heard testimony in this case concerning ... splits of pictures ... by the defendant exhibitors or some of them. So far as the defendant distributors are concerned the testimony indicated that such splits were the products of arrangements entered into by the theatre exhibitors and then presented to the distributors, who, while they did not protest against the splits in most cases, they were not in any case the parties who originated them. ${ }^{00}$

In fact, so representative of splits is this charge that the Second Circuit unwittingly wrote the existence of an exhibitor cartel into its definition of a split:

The so-called "split" system, whereby exhibitors divide the list of available pictures and then approach the distributors separately on that basis, enables them to purchase films at lower prices. $^{70}$

66. The position taken in the text is based upon the reconciliation of Dr. Miles and White Motor set forth in note 62 supra. The language in those opinions does not $8 \mathrm{ccm}$ to require that the restraint be imposed on unwilling parties in a vertical arrangement or that the parties upon whom the restraint is imposed reccive no bencfits from the restraint. The cases can be reconciled at a level which requires that imposition be motivated by the supplier's interest (regardless of collateral benefits to his dealers) and that the primary benefit be enjoyed by the supplier.

67. 372 U.S. at 267 (Brennan, J. concurring).

68. In the instances cited in note 6 supra, for example, the facts with which the author is familiar indicate that the exhibitors agreed among themselves to split and then approached the distributors for their consent-or simply informed the latter of the frit accompli. Judge Clarie's charge, text accompanying note 69 infra, and the Sccond Circult's findings in Royster, text accompanying note 70 infra, are typical.

69. Berlin Drive-In Theatre v. Stanley Warner Management Corp., Civil case No. 8501 (D.C. Conn. 1965) (unreported) (Emphasis added).

70. Royster Drive-In Theatres v. American Broadcasting-Paramount Theatres, Inc. 268 F.2d 246, 250 (2d Cir. 1959). 
Research has disclosed no convincing evidence of distributor imposition, and in some cases even the existence of acquiescence was doubtful. For example, in Viking both the defendants' brief in the Supreme Court $^{71}$ and the Third Circuit's opinion ${ }^{72}$ acknowledge uncertainty about whether all or merely some of the distributors acquiesced to the split of their product. In such cases defendants cannot possibly meet the greater burden of showing vertical imposition.

Assuming, however, a hypothetical defendant could show vertical imposition, only the first hurdle would be cleared. The Thile Motor rule of reason would also require a defendant to show genuine economic justification for the vertically imposed split. Justice Douglas in his opinion for the majority cited only two examples in illustration of possible justifications for White Motors' otherwise illegal market division. If these restraints were found to be "protections against aggressive competitors or the only practical means a small company has for breaking into or staying in business," 73 the majority would presumably have approved. Because White Motors was considered a pygmy in an industry dominated by three of the nation's industrial giants-General Motors, Ford, Chrysler-Justice Douglas' statement is especially pro-competitive. And Justice Brennan in his concurring opinion expressed this policy in a more general and yet pointed sense.

Surely it would be significant to the disposition of this case if, as appellant claims, some such arrangement were a prerequisite for effective competition on the part of independent manufacturers of trucks. ${ }^{74}$

Accordingly, if motion picture distributors are eligible for the limited dispensation offered by White Motors, they would be required to prove that splitting of product enables them to compete more effectively against one another.

In the Viking case, two arguments were made which might satisfy the criteria established in the Douglas and Brennan While Motor opinions. The first and only persuasive argument-that "litigation is lessened when exhibitors agree to a split"is_must be analyzed within

71. Brief for Respondents, p. 18, nn.19 and 20.

72. 302 F.2d at 292. In this regard, Judge Palmieri's opinion in United States v. Loew's, Inc, 1962 Trade Cas. 76373 (S.D.N.Y. 1962), is an interesting study in itself. He devotes three somewhat confusing pages of discussion to the extensive evidence concerning whether or not the distributors in fact acquiesced. In such a situation, for defendant exhibitors or distributors to argue that a distributor imposed the market division a la White Motor would truly be absurd.

73. 372 U.S. at 263.

74. 372 U.S. at 268-69 (Emphasis added).

75. Brief for Amici Curiae, p. 9. 
the peculiar economic and legal milieu of the motion picture industry. Such an analysis in turn requires a brief digression into the mechanics and problems of film distribution.

If competitive bidding or negotiation is the modus vivendi, the distributor is faced with the necessity of deciding between largely incomparable offers. It is well known that distributors consider, in addition to the seating capacity of the competing theatres,

Offered dates of showing - known in the trade as the exhibitor's availability-length of run promised, amount of clearance over competitors desired by the exhibitor, percentage of gross receipts offered, and the parking facilities and physical appointments as well as the location of each theatre. . . .

The most important of these factors, percentage of gross receipts offered, is itself likely to vary from offer to offer. In the Viking record, for example, it developed that

[t]here were proposals in which film rental was based on a flat percentage of weekly gross receipts less house costs for each week, the percentage remaining constant. There were others in which film rental was based on a scale of percentages adjusted downwardly week by week. There were still others in which film rental was based on a sliding scale of percentages, the proposal providing for the upward or downward adjustment of percentages . . . depending on gross receipts. ${ }^{77}$

Additionally, some offers contain cash guarantees payable in the event earned film rental falls below the amount of the guarantee. Merely to state these myriad considerations is to illustrate the extreme difficulty a distributor would face if required to prove that he made a completely objective judgment of the relative merits of the conflicting offers. However, this type of judgment is exactly what the governing law of the industry requires. The Paramount decrees require that each film be offered theatre by theatre, and that all exhibitors be given a fair opportunity to obtain whatever film is released. ${ }^{78}$ By fixing such re-

76. COMMENT at 1086 .

77. 320 F.2d at 289.

78. See COMMENT at 1085 n.171. For history and background of the Paramount case, see generally, Conant, ANTITRUst in the Motion Picture Industry (1960). In United States v. Paramount Pictures, Inc., 334 U.S. 131 (1948), the Government won a total victory over the eight major motion picture distributors (five of which were integrated production-distribution-exhibition companies) under section one of the Sherman Act. Those companies which were integrated with exhibition chains were forced to divorce them completely, retaining no vestige of control over them; and all distribution com. panies were enjoined from favoring their former subsidiaries, from offering films for license in any way other than theatre by theatre, film by film, from granting discrimina. 
quirements, the decrees have provided a cause of action to countless exhibitors throughout the country who consider themselves unjustly treated. ${ }^{79}$ Although many of these suits have been unjustified, the validity of the claims made in the majority is impossible to assess without lengthy and costly litigation.

No one in the industry would dispute the fact that distributors have expended large amounts of their resources in defending against exhibitor suits. Splitting, by eliminating competition in the bidding or negotiating for films, also eliminates the possibility of having an aggrieved party, since only one exhibitor in any particular split territory will negotiate for any particular film. Thus it may be true that distributors spend more in defending against exhibitor suits than would be lost by imposing splits on exhibitors. The net gain might be employed by distributors for increased and improved production, more efficient distribution, and thus more effective competition. The argument based on litigation costs is even more compelling when one recalls that in Paramount Justice Douglas, also the majority's spokesman in the White Motor case, expunged from the lower court's decree the requirement that all films be licensed through competitive bidding. His argument in Paramount raised the same considerations concerning the complexity of bidding and the likelihood of extensive litigation involving the federal courts in the day-to-day conduct of the industry..$^{80}$

tory runs or clearances; and from such common practices as blind booking, block booking. signing franchise agreements, etc. See generally, CoNANT, supra, pasim, and Cossarit at 1085, 1103-04.

79. The Viking case is itself typical, being originally tried on the theory that plaintiff's competitors, Stanley Warner and Goldman, had conspired with the distributors to discriminate against him. See text preceding note 1 supra. The Federal Reports are crammed with similar cases; see the Defendant-Plaintiff Tables, 55, 56 MOD. FED. Pruc. Dic., and cumulative Annual Pocket Parts, under the titles Loew's, Inc., Wamer Bros. Pictures, Inc, Warner Bros. Pictures Distrib. Corp., Paramount Film Distrib. Corp., Paramount Pictures, Inc., and Universal Pictures Co. The several hundred cases listed therein, and in the tables of contents of the various volumes of CCH Trade CASES, do not, of course, invariably involve complaints of conspiratorial discrimination by theatre owners; but the great majority unquestionably do. Attorneys for the defendant Stanley Warner Corp. have explained to the author that avoidance of further litigation with William Goldman, one of the major figures in the dramatis personae of the Viking case, was itself one of the prime causes of the Philadelphia split. He was one of the most tenacious and successful antitrust plaintiffs of all time. See William Goldman Theatres, Inc. v. Locw's, Inc, 54 F. Supp. 1011 (E.D. Pa. 1944), rev'd, 150 F.2d 738 (3d Cir. 1945); 69 F. Supp. 103 (E.D. Pa. 1946), bill of review denied, 163 F.2d 241 (1947), affd, 164 F.2d 102I (3d Cir.), cert. denied, 334 U.S. 811 (1948). $\$ 375,000$ in treble damages were awarded to Goldman. Petition for additional relief was denied, 83 F. Supp. 455 (E.D. Pa. 1949).

80. United States v. Paramount Pictures, Inc., 334 U.S. 131, 162-64 (1948). The argument that since the Paramount opinion and decrees did not require competitive bidding, an exhibitor cartel is justified (see Judge Palmieri's statement in United States v. Locw's, 
The litigation argument is limited in its availability to the defense of splits which include all exhibitors in the area on any particular run. Because non-participating exhibitors are always free to "bid across the split" and the distributors are always free to award licenses to the highest offerors, the possibilities of litigation are hardly lessened if any significant exhibitor is not a member of the split.

The second argument in Viking-that a split "helps the distributor keep the exhibitors, who are his outlets, in business" 81 -is typical of those which the courts should consider unacceptable. It is the old and discredited horizontal argument-ruinous competition-made to look vertical and as such it was properly rejected by the Supreme Court in Dr. Miles Medical Co. v. John D. Park \& Sons Co.82 and the other resale price maintenance cases. ${ }^{83}$ There may well be other arguments which would indicate that distributor imposed splits enhance the competitive standing of distributors. It may be assumed, however, that any such arguments would further illustrate the fundamental tension which underlies an attempt to justify splits under the rule of While Motor. This tension demands that any court faced with such an attempt analyze the arguments carefully and weigh the possible benefits to competition against the economic injury caused by splits. Ultimately it may be necessary for the Supreme Court to hold that on balance splits "may be too dangerous to sanction." 84

Inc., 1962 Trade Cas. ๆ 70347, at 76374 (S.D.N.Y. 1962); and Brief for Amici Curiac, p. 9, Viking Theatre, Inc. v. Paramount Pictures, Inc., 378 U.S. 123 (1964)), must, of coursc, bc completely rejected. The argument from Paramount is available only in a case where the defendants have brought themselves within the White Motor dispensation, having pissed the first hurdle by showing that the split was vertically imposed.

81. Brief for Amici Curiae, p. 10. The defendants made the same argument in a somc. what more sophisticated manner:

The more theatres doing business, the higher a distributor's total income. The distributor has an obvious interest in the economic success of a large number of exhibitor customers. The decline in the number of theatres which followed the advent of television, and the consequent decrease in the number of films produced, certalily warrants a distributor's concern for the preservation of as many outlets as possible.

Brief for Respondents, p. 37. This "preservation of outlets" theory has, it should be noted, failed dismally in the resale price maintenance cases, where suppliers have tried to justify maintenance of higher profit margins for their dealers through vertically imposed price fixing. See discussion note 66 supra, and see, e.g., United States $\%$. Parke, Davis and Co. and Dr. Miles Medical Co. v. John D. Park \& Sons Co., note 62 supra.

82. 220 U.S. 373 (1911). See note 62 supra.

83. See note 49 supra.

84. In remanding, Justice Douglas stated:

They [White's territorial restraints] may be too dangerous to sanction or they may be allowable protections against aggressive competitors or the only practicable means a small company has for breaking into or staying in business.

Id. at 263. 


\title{
THE YALE LAW JOURNAL
}

\author{
Peter L. Zimroth \\ E. Edward Bruce \\ Cameron F. Macrae, III \\ Editor-in-Chief \\ BenNo C. SchMidt, JR. \\ LARRY G. SIMON \\ Note \& Comment \\ Editors \\ BETSY LEVIN \\ Topics Editor \\ Rayaiond C. Clevenger, III \\ MAARK A. WALFER \\ Article \& Bool \\ Review Editors
}

BRuce ACKerman

JOHN R. ADLER

STEPHEN BOMSE

Charies N. Burger

Thomas Childers

BarRy Cratg

WALter E. DEIIINGer, III

ARDEN DOSS, JR.

W. LEE H. DUNhaMr

Virginia B. EISENSTEIN

JoHN Evans

GREGORY C. GLYNN

RICHARO GoOdyear

H. JEFF GREENFIELd

Charles H. Herz

DENNis E. CurTis

Managing Editor

David Hess

B. Boyd Hight, JR.

ALAN C. HOOKER

C. StEPHEN HOWARD

George A. Johnson

George L. JuRow

LINDSEY C. Y. KIANG

Howard A. KNIGhT

Simon LAzARUS, III

RONALD F. LIPP

PhILIP LOCHNER

Victor MAARrero

Alan R. MfcFarland, JR.

Frederick B. Mclane

Theodore MIUIER
Mfichael Mfuraser

JorN E. NAthLA

JOSEPH N. ONES:

Donaldon C. Plllsaugr

Cimartes A. Pulashi, Jr.

Leonard M. Ross

Phitup Gordon Schrac

ALAN D. SIstTsky

Allan G. Sperdinc

Leonard P. Strickaman

Robert Tanner

DAvid F. TILLOTSON

Mifchael S. Wald

ROBERT F. WALKER

Silas Wasserstroat

M. OtIVE Butterfatd

Business Secretary

\section{CONTRIBUTORS TO THIS ISSUE}

Marvin A. Chireistetn. A.B. 1950, University of California; J.D. 1953, University of Chicago.

Gumo CALABRESI. B.A. 1953, LL.B. 1958, Yale University; B.A. 1955, MI.A. 1959, Oxford University.

JAMES S. GoRdoN. B.A. 1962, University of Florida; LL.B. 1965, Yale University.

Broadus Mrrchell. A.B. 1913, University of South Carolina; Fellow 1917-1918, Ph.D. 1918, Johns Hopkins University.

Thomas F. Bergin. B.A. 1948, Princeton University; LL.B. 1951, Yale University.

John P. FrANE. B.A. 1938, M.A. 1940, LL.B. 1940, University of Wisconsin; J.S.D. 1947. Yale University.

John D. Butzaner. B.A. 1939, University of Scranton; LL.B. 1941, University of Vinginia. 